\title{
MONGOL-ARMENIAN COOPERATION: STAGE III
} (1265-1295)

As has been mentioned previously, the Mongol-Cilician Armenian partnership had great success at the beginning. However, conflicts within the Mongol Empire prevented the Mongol advance into the Near East, although the Mongols did not give up the idea of marching on northern Syria. Hülegü's successors made a series of approaches to various leaders to gain Latin support, including the Popes and the Kings of France and England. Meanwhile, the Mamluks became a more and more powerful adversary of the Il-Khanate and their hostility towards Cilician Armenia for being a Mongol ally intensified. The Christian States on the Syrian coast, seeking a chance of survival, saw in the Mongols a realisation of the Popes' dreams of 'Prester John. ${ }^{82}$ Over time, their hopes vanished with the conversion to Islam of the Mongols of the Golden Horde and the Il-Khans. The purpose of this chapter is to discuss the development of Mongol-Armenian military collaboration during the Mongol conquest of the Syrian coast, which eventually grew into a relationship that implicated not only the Mongol Il-Khans and the Armenian lords, but also the Mamluk Sultans and the Christian powers in that particular period.

After the death of Hülegü, the Armenians carefully watched the accession of each Il-Khan and the policy that would follow. The Cilician Armenians tried to use every possible moment to draw the Il-Khans' attention towards their own interests in order to safeguard their lands and rights. In fact, they succeeded in this as long as the Mongols' interest coincided with theirs and remained strong enough to invade the Syrian coast. Examination of the contemporary Armenian sources reveals that the Armenians expected that each Il-Khan would give serious attention to Mongol-Armenian affairs.

${ }^{82}$ The Pope and the King of France were aware of the danger of assisting Mongol armies; however, the Mongols were their only means of breaking the Muslim bondage. The belief in Prester John had grown since 1141, when the Seljuks were defeated by a non-Muslim army from Central Asia, who they thought were Nestorian Christians (Spuler, 1960:29; Jackson, 1999a:711). 
Generally, the Armenian sources are positive towards the Il-Khans Abaqa (r. 1265-1282) and Arghun (r. 1284-1291), mainly due to their sympathy for the Christians. As for the Il-Khans Tegüder Ahmad (r. 1282-1284), Geikhatu (r. 1291-1295), Baidu (1295), Ghazan (r. 1295-1304), Öljeitü (r. 1304-1316) and Abū Sa'īd (r. 1316-1335), the Armenian sources provide rather diverse information. In order to illustrate this statement it is proposed to analyse the historical circumstances under which the Mongols, Armenians and the Mamluks lived and fought.

\section{The Strongest Pairing of Abaqa and Het'um I against Baybars}

Among the Armenian kings of Cilicia, Het'um I (r. 1226-1269) proved himself to be the wisest, most powerful and farsighted monarch. Among the Mamluk Sultans, Baybars al-Bunduqdārī (r. 12601277) was one of the strongest opponents of the Armenians and the Mongols. ${ }^{83}$ Baybars aimed to efface Cilician Armenia from the medieval map. ${ }^{84}$ Among all the Il-Khans, Abaqa's reign (r. 1265-1282) stands out in terms of the entangled nature of his relations with Greater Armenia, Cilician Armenia, the Chinggisids and the Franks. ${ }^{85}$ In addition to this, his diplomacy towards the Mamluks exclusively concerned the questions of the Cilician Armenians.

The relationship between Abaqa and King Het'um I is one of the major defining episodes of Mongol-Armenian collaboration. It was bound to take place after Sultan Baybars al-Bunduqdārī (Tinnı/unum) began his steady advance through Syria to Cilicia. Caesarea, Haifa, Arsuf, Tibnin and Șafad (Safeth) fell to Baybars in

${ }^{83}$ The enlargement and improved training of the Mamluk army along with an efficient espionage system and civilian administration were put into force during Baybars' reign (Amitai, 2005:359-360).

${ }^{84}$ Stewart, 2001:190.

85 Abaqa was the eldest son of Hülegü by Esunjin Khatun, and came to Iran with his father in 1256. According to an Armenian source, he was the most good-looking and well-built among his brothers (Grigor Aknerts'i, 1974:52). Abaqa had 13 (not 30 as Grigor Aknerts'i states) brothers and seven sisters (Rashīd al Dīn, 1954:679). He succeeded to the throne as the Il-Khan of Persia on 19 June 1265. The enthronement took place on the shores of Chaghan Na'ur (White Lake) in the district of Farāhān, to the north of Sulțānābād. However, it was only on 26 November 1270, five years later, that the decree of the Great Khan arrived, and he was enthroned for the second time. Abaqa chose Tabriz as his capital with Summer residences in Ala-Tagh and Siyāh-Kūh, and Winter residences in Baghdad, Arran and in the valley of Jaghatu (Ibid., 742-743, 765). 
1265-1266, signifying the beginning of the end for the Franks in Syria. It was clear that the Sultan would turn on Cilicia, the main ally of the Mongols. ${ }^{86}$ Besides this, it is worth noting that on the eve of the Mamluk advance, the Cilician Armenian economy was flourishing due to foreign trade and manufacturing. The flow of labour increased due to refugees from Greater Armenia and other regions during the 1240s-1250s, who had escaped Mongol pressure. ${ }^{87}$ The wealth of the country surely attracted its neighbours. Cilician Armenian ports on the shores of the Mediterranean Sea made Cilician Armenia participate actively in the international trade of the region. According to Western travellers, the most important port was Ayas, where spices and food of all sorts, silk and woollen goods and other rich commodities were traded. ${ }^{88}$ Therefore, control over Ayas would challenge the Sultans constantly. ${ }^{89}$

Seeing the growing aggression of the Mamluks, King Het'um I tried on his own to negotiate a peace treaty with Baybars, for which, as Smbat Sparapet records, some embassies were exchanged, but the Sultan was too demanding. ${ }^{90}$ Het'um refused to accept the conditions surrounding certain frontier holdings. This can be explained for two reasons. Firstly, the Armenian monarch was afraid of the anger of the Mongols, who would blame him for having fallen under the influence of the Sultan if he gave him the fortresses the Mongols had captured. Secondly, the Sultan wanted Het'um to give him a less ruined frontier holding called Shih $(\tau h h)$ with a view to making it a marketplace for trade. Het'um could not accept these conditions, because allegedly 'he had been a victorious and famous King for many years, while the Sultan who had been the servant of disreputable servants had later become so powerful that all feared him. ${ }^{.91}$ As Grigor Aknerts'i suggests, there was another motive as well. Muslim advisers at the court of Abaqa Khan were secretly seeking ways to undermine Mongol trust in the Cilician Armenians. These advisers wrote to the Sultan of Egypt telling him to obtain at least one village

\footnotetext{
${ }^{86}$ Smbat Sparapet in Galstyan, 1962:59; Der Nersessian, 1973:373.

${ }^{87}$ Mikaelean, 1952:339, 346.

${ }_{88}$ Marco Polo, 1987:20.

${ }^{89}$ Stewart, 2001:187.

${ }^{90}$ Smbat Sparapet in Galstyan, 1962:59; Der Nersessian, 1973:374.

91 Smbat Sparapet in Galstyan, 1962:59-60.
} 
from the Armenian King, which would be sufficient reason to claim that the Armenian King had breached his vow with the Mongols. ${ }^{92}$

For many reasons, the position of Cilician Armenia became precarious and there was sufficient reason for Het'um to rush to seek Mongol help in $1266 .{ }^{93} \mathrm{He}$ divided his forces into three groups: one he took with him; the second was stationed at a place called the Gate $\left(7 n\left\llcorner n\{)\right.\right.$; while the third was at a place called Mari (Marrī).${ }^{94}$ In his absence, Baybars sent the Mamluk army under the command of his amirs to cross the Amanus Mountains and enter Cilicia as far as Sis, Adana and Bardzraberd. ${ }^{95}$ Smbat Sparapet with the two young princes, T'oros and Lewon, led the Armenian forces against the Mamluks at Mari but were routed. T'oros was killed; Lewon and Smbat's Mongol son Vasil were captured and sent to Egypt. ${ }^{96}$ When Het'um returned two days ahead of the Mongol troops who had been sent to aid him, he found Sis set on fire, the port of Ayas devastated and the whole country destroyed. ${ }^{97}$ Serious damage was done to the Cilician economy, for which the lords of Cilician Armenia blamed Het'um, claiming that by his refusal to hand over to the Mamluks a fortress at Shih had brought their whole country to misfortune and cost him the loss of his sons. ${ }^{98}$

T'oros' death and Lewon's capture led Het'um to seek help from the Papacy. This was one of five appeals by the Cilician Armenian kings written to Western kings and the Papacy for aid and support against Egypt. ${ }^{99}$ Pope Clement IV (1265-1268), who had encouraged Het'um to assist the Syrian crusaders earlier on, expressed his condolences and asked the Byzantine Emperor to help the Cilician Armenians, but Michael VIII Palaeologus was not remotely interested in doing so. ${ }^{100}$

92 Grigor Aknerts'i, 1974:59.

${ }^{93}$ Grigor Aknerts'i says that King Het'um went with a small detachment to the Mongols who were stationed between Abulistan and Kokoson (Grigor Aknerts'i, 1974:54).

${ }^{94}$ Smbat Sparapet in Galstyan, 1962:60.

${ }^{95}$ Het'um Patmich', 1956:73; King Het'um II, 1962:73; Der Nersessian, 1973:373-374; cf. Thorau, 1992:192-193.

${ }_{96}$ Smbat Sparapet in Galstyan, 1962:60-61; Het'um Patmich', 1956:73; Boase, 1978:26.

${ }_{97}$ Grigor Aknerts'i, 1974:54; Sebastats'i in Hakobyan, 1956:145-146; Vahram, 1831:50-51.

${ }_{98}$ Grigor Aknerts'i, 1974:59.

99 Lloyd, 1988:25.

${ }^{100}$ Mikaelean, 1952:344; Richard, 1992:516-517. 
His refusal had its own reason. It was connected to Abaqa's marriage, a political affair that involved many parties. Abaqa was given a Christian wife, Maria Despina Palaeologina in $1265 .{ }^{101}$ This marriage was blessed by the Patriarch of Antioch, by Sargis, the Bishop of Erznka, and someone called Vardapet Bener, ${ }^{102}$ exemplifying the positive character of the Christian clergy towards Christian marriages with the Mongols. This marriage alliance with the imperial dynasty of Constantinople was part of a series of political actions that involved many parties in double-dealing. Firstly, it could be interpreted as one of the Il-Khan's tactical moves to find an ally and to secure the Il-Khanid position, which was threatened by the Golden Horde and its coalition with the Mamluks. Secondly, it provoked Sultan Baybars, who was carefully watching the outcome of the alliance between the Il-Khanate and Michael VIII, and was anxious about the Il-Khan's relations with the Franks, to pursue measures that would counter the Il-Khanate-Byzantine union. Berke of the Golden Horde persuaded his victorious nephew Noqai (d. 1299) to marry another illegitimate daughter of the Emperor Michael VIII, Euphrosyne Palaeologina, in 1266. ${ }^{103}$ In this way, the Golden Horde was supported by both Egypt and Byzantium. As for the Byzantine Emperor, this decision to marry his daughters to Abaqa and Noqai was a serious attempt to play a twofold game out of concern for his own position in the region. This was surely a political action, which to some extent supports Saunders' definition of a Mamluk-Qipchak-Byzantine alliance against the Il-Khanate and the Latins. ${ }^{104}$ In fact, Michael VIII himself had no desire to see the power of the Franks growing in the Levant or to share his business on trade routes. The Byzantine Emperor, who

101 Step'annos Orbelian, 1910:470. The Byzantine Emperor Michael VIII Palaeologus (1261-1282), who had controlled the truncated Byzantine realms from Nicaea since 1259, was actually frightened when one of the two joint Seljuk rulers, Izz al-Dīn, was dethroned by Hülegü in 1262, and fled to Constantinople. In order to assure his friendship towards the Il-Khan, Michael offered him his illegitimate daughter in marriage (Saunders, 1977:70-71). However, Maria arrived after his death, so she was given to his successor (Jackson, 1999b:710; Nicol, 1993:80-81).

${ }^{102}$ Kirakos Gandzakets'i, 1964:399.

${ }^{103}$ Lamb, 1940:249; Nasonov, 1940:44; Vásáry, 2005:79. Noqai controlled the western frontiers of the Golden Horde. In 1265, he led his army across the Danube, making the Byzantine forces flee, and devastated the city of Thrace. Therefore, this marriage was important for the Emperor. Vernadsky dates it to 1273 (Vernadsky, 2001:172). In 1286, Noqai plundered Poland mainly for provisions (De Hartog, 1996:70).

104 Saunders, 1977:74, 1971:131. 
expelled the Franks from Constantinople in 1261, was apprehensive of every new crusade. ${ }^{105}$ Therefore, to prevent new assaults on Constantinople, he decided to court both the Mamluks and the Golden Horde. In addition to this intrigue, Baybars made another attempt at a Byzantine-Mamluk alliance against the Il-Khanate and the Frankish states. He opened up commercial relations with Genoese merchants for a slave trade via Constantinople. ${ }^{106}$ The Emperor offered Baybars the territories and sea-routes that were under his own control, so that the Golden Horde and Egypt could communicate with each other through diplomatic missions, the slave trade, the most profitable commerce of that time, and by other means. ${ }^{107}$ Therefore, the Emperor's interests did not coincide with those of the Pope and the Armenians. However, the Emperor could not neglect his relationship with the Il-Khan. In 1263-1265, Michael Palaeologus held up the Sultan's envoys to Berke only because he was afraid that Hülegü would suspect him of assisting his enemies' passage. ${ }^{108}$

This situation prompted Het'um to initiate a series of diplomatic interactions with Baybars in order to negotiate conditions for Lewon's return. ${ }^{109}$ In 1266, the Armenian ambassador was received by Baybars in Cairo. In 1267, the second mission of Het'um was sent to meet the Sultan in Syria. ${ }^{110}$ According to the Armenian and Mamluk sources, it is likely that Het' um at the outset offered both money and several landholdings to Baybars, who in his turn also demanded the forts taken by the Mongols in 1260 along with the release of his friend Sonqur al-Ashqar who was in Mongol captivity. ${ }^{111}$ Now the Mongols were the only supporters of Het'um's deal. Het'um had no problem in convincing Abaqa because the Il-Khan himself was interested in establishing a good relationship with Baybars. Earlier on, in 1265-1266, Abaqa sent his first embassy to the Sultan with a present

105 Zakirov, 1966:27.

106 Thorau, 1992:121.

107 Saunders, 1977:71-73.

108 Tizengauzen, 1884(Vol. 1):190; Nasonov, 1940:41.

109 Smbat Sparapet in Galstyan, 1962:61.

110 Ibid., 62; Amitai-Preiss, 2004:118.

111 Sonqur, whose name is spelled in Armenian texts as Sghur $\left(\boldsymbol{U}_{\boldsymbol{\eta} \boldsymbol{n} \iota \boldsymbol{\eta}}\right.$, Grigor Aknerts'i, 1974:61), or Sngurashkhar (Smbat Sparapet in Galstyan 1962:62), was a colleague (khushdāsh) of Baybars who helped the latter to escape from the Mongols in the battle for Aleppo, giving him his fine horse while himself mounting a poor horse of Baybars' (Grigor Aknerts'i, 1974:61; Smbat Sparapet in Galstyan, 1962:61; Amitai-Preiss, 2004:118). 
and 'calling for peace,' which meant a peaceful submission. ${ }^{112}$ Seemingly, this act had no result. However, in 1267, Het'um himself went to Abaqa's court but was told that the Mamluk prisoner Sonqur al-Ashqar was not to be found. ${ }^{113}$ In 1268, Lewon, the son of Smbat Sparapet, was sent to the Mongols to ask Abaqa's permission to look for Sonqur al-Ashqar among the soldiers stationed in remote garrisons. ${ }^{114}$ Finally, Sonqur al-Ashqar was found married to a Mongol wife with several children. ${ }^{115}$ With the help of Abaqa Khan and an agreement to give the Mamluks six important fortresses in addition to an exchange of prisoners, Het'um finally secured the release of his son Lewon, who had been held for one year and ten months in captivity in Egypt. ${ }^{116}$ Strangely enough, the Armenians brought two adversaries, Abaqa Khan and Sultan Baybars into diplomatic contact. ${ }^{117}$

The Armenian King decided to exploit further this diplomatic contact established between two sovereigns. After the conquest of Aleppo, Hülegü had taken prisoner some other Bahrī Mamluks. Baybars kept other Armenian prisoners in captivity. The children of Sonqur al-Ashqar were left with the Mongols. Het'um, knowing this and realising that he could reinstate his weakened authority only if the Mamluks and the Mongols, two equal powers in the region, ended their mutual hostilities, offered himself as an intermediary, peacemaker and negotiator with the Mongols in his letter to Baybars written in $1268 .{ }^{118}$ The Sultan permitted the Armenian King to deal on behalf of Sonqur al-Ashqar with the negotiations concerning only the children. Het'um somehow misled Abaqa Khan about the Sultan's message, and Abaqa understood that the Sultan agreed to submit to the Mongols and agreed to the release of the Bahrin Mamluks. ${ }^{119}$ The Il-Khan sent his verbal message through the official envoy via Cilicia. A letter written in December 1268 in Baghdad followed. In his answer, Baybars stated that the Armenian King had no right to deal

112 Amitai-Preiss, 2004:120.

113 Smbat Sparapet in Galstyan, 1962:62.

114 Ibid., 62.

115 Amitai-Preiss, 2004:120.

116 Grigor Aknerts'i, 1974:61; Het'um Patmich', 1956:74.

117 The involvement of Het'um in the exchange of envoys and letters between Abaqa and Baybars, based on Mamluk sources, was examined by Amitai-Preiss, 2004:120-122.

118 Amitai-Preiss, 2004:120-121.

119 Ibid., 121-22. 
with any other matters except Sonqur's children, and having reminded Abaqa about Ket-Buqa's defeat in 'Ayn Jalūt, he refused to submit. ${ }^{120}$ The Armenian monarch and the Mongol Il-Khan were taught a lesson that their opponent was more powerful than they thought. Consequently, Abaqa did not achieve any peace-treaty with BaybarsIf the Mamluks were the only main adversary of the Armenian King, there was another important matter for the Il-Khan to deal with constantly. This was warfare among the Chinggisids in which Greater Armenia was involved.

\section{Greater Armenia and the Struggle with the Golden Horde}

Once settled on the throne, Abaqa appointed commanders and officials all over his domains. Georgia and Greater Armenia were placed under the supervision of Shiramun, the son of Chormaghan. ${ }^{121}$ Shams al-Dīn Juvaynī retained the office of vizier. His brother 'Ala al-Dīn 'Ata-Malik Juvaynī, the historian, who was previously the governor in Baghdad in Hülegü's time, became a lieutenant to Sunjaq Noyan, the governor of 'Irāq-i 'Arab and Fārs. The Juvaynī brothers aimed to transform Mongol rule into the old model of Iranian kingship. The revival of Takht-i Sulaymān, the Iranian pre-Islamic site of the kings, was part of their scheme to represent Mongol rulers as the heirs of the Sassanians. ${ }^{122}$ As for Greater Armenia, as has been said earlier, the Zak'arian House had lost its leading role to the Artsrunids. Sadun Artsruni was appointed as atabeg of Georgia by Abaqa Khan. ${ }^{123}$ Being unable to pay taxes to the Il-Khanid court, Shahnshah Zak'arian had to trade a part of the city of Ani to Shams al-Dīn Juvayni in 1263. ${ }^{124}$ The latter befriended Sadun Artsruni and was married to Sadun's protégée Khoshak, the daughter of Awag Zak'arian and Gontsa. Although the Zak'arids were in decline, this marriage gave the Zak'arids a chance to reinstate the dignity of their House. ${ }^{125}$ Beside the Artsruni family, the House of Orbelian gained a strong position through Prince Tarsaich, the favourite of Abaqa. ${ }^{126}$ Other

\footnotetext{
120 Ibid., 122.

121 Rashīd al Dīn, 1954:743.

122 Melville, 2003a:54.

123 Step'annos Orbelian, 1910:418; Melikset-bek, 1936:60.

124 Babayan, 1976:633.

125 Ibid., 633.

126 Step'annos Orbelian, 1910:423.
} 
important families were the Dop'ians, the Vach'utians and the Vakhtangids. ${ }^{127}$ These families were in the service of Abaqa for his expeditions to Syria and fought with him against the Chinggisids of the Golden Horde and the Chaghatai Ulus.

The Golden Horde actively involved Abaqa in military conflicts from the very beginning of his reign until 1267. When the Il-Khan renewed his fight with Berke in the territories of the Caucasus, this time on the shores of the River Kur in Georgia, the Caucasus was again involved into Mongol warfare. ${ }^{128}$ The Armenian and Georgian farmers were the primary victims of this action, since they were obliged to feed and accommodate one or other party of the Mongol Khans. ${ }^{129}$ Although the battle ended victoriously for Abaqa, leaving Noqai to lose one eye and Berke to die from sickness on his way to Tiflis in $1266,{ }^{130}$ the Greater Armenian economy deteriorated greatly. ${ }^{131}$

In addition to the Golden Horde, constant hostilities from the Chaghatai Khanate ${ }^{132}$ towards the Il-Khanate became another challenge for the Armenians. When Abaqa defeated the Golden Horde, Baraq Khan (r. 1266-1271), the ruler of the Chaghatai Khanate, tried to take over Iran. ${ }^{133}$ Another grandson of Chaghatai, called Tegüder or Negüder (fl. 1266-1269, not to be mistaken for Il-Khan Tegüder Ahmad), who came to Iran with Hülegü and stayed with Abaqa in his ordu (headquarters) along with his one tuman of cavalry men, was provoked by Baraq to rebel against Abaqa Khan in 1268. ${ }^{134}$ When Tegüder left Abaqa for his own fief in Gurjistan vilayet, from where through Derbent he aimed to join Baraq, the Il-Khan sent Shiramun,

127 Babayan, 1976:634.

${ }^{128}$ Kirakos Gandzakets'i, 1964:399. Rashīd al-Dīn states that the army of Noqai crossed the River Kur and the actual battle occurred on the shores of River Aksu which the Mongols called Chagan Moren (White River) (Rashīd al-Dīn, 1954:744).

129 Bedrosian, 1996:133.

${ }^{130}$ Rashīd al-Dīn, 1954:744.

${ }^{131}$ Manandian, 1952:301.

132 The Mongol Empire in Turkestan.

${ }^{133}$ Baraq, as a descendant of Chaghatai, was disappointed that the Toluids, Qubilai and Abaqa held better pastures and bigger lands. After a council with Qaidu, the grandson of Ögedei, and Möngke-Temür, the great-grandson of Jochi, Baraq decided to invade Iran. He also resolved his earlier conflicts with Qaidu, regarding the lands of Mā warā' al-nahr, and the lands between the rivers of Syr Darya and Amu Darya, giving Qaidu and Möngke-Temür one-third of these lands and keeping two-thirds for himself (Rashid al-Dīn, 1954:749; Biran, 1997:57).

${ }^{134}$ Rashīd al-Dīn, 1954:749. 
the son of Chormaghan, who was in charge of the Caucasus, to pursue Tegüder. ${ }^{135}$ According to the description of Grigor Aknerts' $i$, Tegüder was fond of wealth and was thus prone to pillage and slaughter. ${ }^{136}$ For this reason, Georgian-Armenian forces under the standard of the Il-Khan fell on Tegüder's troops and mercilessly slaughtered them. They took all of his treasures. ${ }^{137}$ Tegüder surrendered in the Autumn of 1269 in a forest in Georgia and was imprisoned for a year on the island on Lake Urmīya (Darīa-ye Kabūdān) and then released after Baraq's death. ${ }^{138}$

In the meantime, Baraq Khan claimed the meadowlands of Badghīs in Herat, which belonged to Tübshin, the youngest brother of Abaqa. Tübshin, with the assistance of Arghun Aqa (Amir Arghun), was unable to oppose Baraq and retreated to Māzandarān to await Abaqa's main army. Baraq made his headquarters in the Țāliqān area and succeeded in taking the greater part of Khurasan. After pillaging Nīshāpūr, Baraq was about to conquer Herat but Abaqa, through trickery, made Baraq withdraw his forces to the banks of the River Harī, where the battle (called the Battle of Herāt) between the Il-Khanate and the Chaghatai Ulus commenced in July $1270 .{ }^{139}$ Baraq escaped across the Oxus but afterwards he was paralysed by fear that Qaidu would destroy him and died. ${ }^{140}$

Being victorious in the battles against the Golden Horde and the Chaghatai Ulus, Abaqa Khan himself did not take any major part in military action afterwards. ${ }^{141}$ Rather, he was keen to secure his own empire by restructuring the imperial taxation and monetary policy. ${ }^{142}$ Nonetheless, the western frontiers of his domain were constantly troubling him.

${ }^{135}$ Ibid., 750; Babayan, 1976:632.

${ }^{136}$ Grigor Aknerts'i, 1974:63.

137 Ibid., 64.

${ }_{138}$ Rashīd al-Dīn, 1954:750.

139 Ibid., 755-765; Biran, 1997:62-63, 2002:175-219. For the ode on the restoration of Nishapur, see Minorsky, 1964d:292-305.

140 Rashīd al-Dīn, 1954:755-765. On Qaidu, see Biran, 1997.

${ }^{141}$ In 1271, the Ismā' îlī stronghold Girdkūh finally surrendered (Rashīd al-Dīn, 1954:766).

${ }^{142}$ For numismatic evidence for these reforms, see Kolbas, 2006:193-234. 


\section{Lewon III and Abaqa against Baybars}

Het'um I, seeing that the Mamluks had stormed Antioch and that many refugees had escaped to Cilicia, and that, after a severe earthquake in Cilicia, many places were in ruin, ${ }^{143}$ he abdicated in 1269 in favour of his son Lewon III (r. 1269-1289) and retired to a monastery. But before becoming a monk called Makar, ${ }^{144}$ Het ${ }^{\text {'um sent }}$ Lewon to Abaqa Khan to acknowledge and introduce his son as the next Cilician Armenian king. The Il-Khan Abaqa confirmed his position, ${ }^{145}$ and a year later, in 1270, after a reign of 44 years, King Het'um I died. ${ }^{146}$

The strongest phase of Mongol-Armenian military collaboration was continued by Lewon and Abaqa. When in 1271, Lewon III was anointed king in the Church of St. Sophia at Tarsus, ${ }^{147}$ Baybars set out for Cilicia again to challenge the new king; however, King Lewon, proving that he was a capable ruler, sent a mission to negotiate, and Baybars returned to Egypt. ${ }^{148}$ Meanwhile, Lewon rushed to Abaqa Khan, who offered him 20,000 men to safeguard Cilician Armenia and promised that he would himself come to Cilicia a few months later. Apparently, Lewon returned home taking with him Abaqa's soldiers. ${ }^{149}$

In 1274, King Lewon sought the help of the Mongols again. The wealthy Greek princes of his kingdom were plotting against the Armenian kingship in Cilicia, demanding that the latter profess their faith. King Lewon seized some of them and dispatched them to Abaqa Khan who executed them. ${ }^{150}$ Next year, in 1275, the Mamluks again attacked the coastal plain of Cilicia. ${ }^{151}$ The Arab sources, Ibn Shaddād and Mufaḍdal, justify this invasion as a response to provocation by $\mathrm{Mu}$ 'īn al-Dīn Sulaymān Pervāne, the Rūmi Seljuk, who

\footnotetext{
${ }^{143}$ Smbat Sparapet in Galstyan, 1962:62-63.

${ }^{144}$ Vahram, 1831:53.

145 Smbat Sparapet in Galstyan, 1962:63-64; Het'um Patmich', 1951:57.

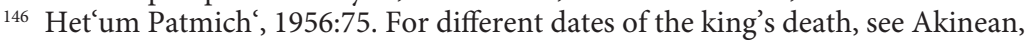
1948:278-279. The Georgian King David Ulu also died in the same year (Grigor Aknerts'i, 1974:62; Step'annos Episkopos, 1951:44).

${ }^{147}$ Smbat Sparapet in Galstyan, 1962:64. In one of the colophons written in 1275 in southern Armenia, the Cilician King Lewon III was considered as the King of all Armenians (RHC/DA, 1869[Vol. 1]:606; Mikaelean, 1952:348).

148 Smbat Sparapet in Galstyan, 1962:64.

149 Ibid., 64.

150 Grigor Aknerts'i, 1974:66.

151 Sebastats'i in Hakobyan, 1956:146.
} 
invited Baybars to take his chance over Rūm, but suggested the Mamluk Sultan neutralise the Cilician Armenian Kingdom first. ${ }^{152}$ Bar Hebraeus records that Lewon understood that Baybars would be interested in invading Rūm (in 1277) and in having access to Caesarea via Cilicia. Therefore, he repeatedly warned the Mongols about this threat but without any success. ${ }^{153}$ Another motive for this incursion was the discontinuation of the tributes paid by the Armenians to the Sultan. Baybars considered this as a breach of the Armenian-Mamluk treaty, the exact conditions of which are not known. ${ }^{154}$ Whatever the precise reason may have been, the Mamluks started their raids in Cilicia. Through his intelligence network, Baybars knew that Abaqa was too busy on his eastern borders and there was no significant Mongol force in Cilicia. ${ }^{155}$ The Mamluks devastated Marash as a prelude to their main campaign, and having no actual battle with the Mongols to bar his way, Baybars entered the capital Sis via the Syrian Gate in March $1275^{156}$ (see Map 2). Bar Hebraeus asserts that the Mamluks reached as far as Korikos (Gorycus) by killing, plundering and burning. ${ }^{157}$ There was another minor raid by some Seljuk amirs sent by Baybars to Cilicia in 1276, from the direction of Marash, which was successfully repulsed, although Smbat Sparapet was killed along with many other Armenian nobles in this battle. ${ }^{158}$ In 1277, from Syria, Baybars raided Abulistān (Abulustayn, Elbistan), the territory of the Rūmi Seljuks, and having defeated the Mongol army commanded by three amirs, he came to Caesarea. ${ }^{159}$ In the same year, in Ala-Tagh the Mongols killed Mu īn al-Dīn Sulaymān Pervāne and many of his army, who had supported Baybars. ${ }^{160}$ Although King Lewon III did not receive much Mongol assistance, he continued his father's pro-Mongol policy. However, he looked upon Western help as well. In 1278, Lewon's envoys came to Edward I of England (r. 1272-1307). The precise purpose of their visit is unknown. Lloyd

152 Stewart, 2001:50-51. On Pervāne's activity in Anatolia, see Melville, 2009:51101.

153 Bar Hebraeus, 2003:456-457.

154 Amitai-Preiss, 2004:134; Stewart, 2001:50.

155 For the Mamluk intelligence network, see Amitai-Preiss, 2004:139-152.

156 Thorau, 1992:233; Amitai-Preiss, 2004:134-135.

157 Bar Hebraeus, 2003:453.

158 Ibid., 454; Thorau, 1992:237.

159 Melville, 2009:51-101.

160 Step'annos Episkopos, 1951:45; Rashīd al-Dīn, 1954:768; Het'um Patmich', 1951:55-56. 
suggests that it was probably connected with securing Edward's aid or a crusading vow. ${ }^{161}$ Nevertheless, it is certain that Lewon believed that the Latin alliance with the Mongols would save not only his own realm, but also the Holy Land.

\section{The Mongols' Appeal to Latin Christendom}

It was not only the Armenians who sought Latin support. ${ }^{162}$ The Mongol Il-Khans were the most active Chinggisids to address the Western powers. Their main reason to do so was related to the political circumstances that the Il-Khanate experienced. The division of the Mongol Empire into Uluses (independent appanages), the intensification of hostilities among them and thus the raids of the Golden Horde on the frontier pastures of Azerbaijan through the Caucasus certainly provoked the Il-Khans. These ventures made the Il-Khans consider their status. Their target was again Palestine and Syria, despite the fact that their previous experience showed them that the climate and pasture of these areas were not suitable for the Mongols. Scholars agree that the capacity of Syria to feed a large Mongol army was limited. Leaving this notion aside, to which we will return later, a brief introduction to the Mongol efforts in trying to achieve Latin support over Syria merits attention because these actions touched the Armenians' sore spot.

Hülegü and his successors pursued the idea of invading Syria, although for different reasons. However, they realised that, without Western involvement, they could not make any progress. They also believed in playing on the sensitivities of the Christians in regaining the Holy Land. Hülegü was the first Il-Khan to write a letter to the French King Louis IX in $1262 .{ }^{163}$ He sought the French King's assis-

\footnotetext{
161 Lloyd, 1988:254.

162 Matthew Paris (ca. 1200-1259), an English chronicler, left an account dated as early as 1249, of the Mongol embassy that requested Latin support against the Muslims. He referred to a Mongol embassy sent by General Eljigidei (Eljidei) to the French King Louis IX (1226-1270) in December 1248 (Matthew Paris, VI, No.84). The Mongols had proposed simultaneous operations against the Muslim powers long before the establishment of the Il-Khanate (Lloyd, 1988:261; Jackson, 2005a:98-99; Amitai-Preiss, 2004:15). On Eljigidei and his mission, see Jackson, 1980:483-484, 1998:366; Richard in Aigle, 1997:57-69).

${ }^{163}$ Earlier, in 1246, and 1247, some letters had been exchanged between Pope Innocent IV and Güyük Khan and between the Pope and Baiju Noyan in 1247 (Lupprian, 1981:182-198).
} 
tance for a French naval fleet to blockade Egypt against the Mamluks. ${ }^{164}$ The letter had no result. On the contrary, Frankish embassies from Jerusalem, Cyprus, Italy and Sicily were sent to Baybars with an aim to maintain good relations with Cairo. ${ }^{165}$

The Il-Khan, Abaqa, had been sending letters to the Pope since $1266 / 1267$. His increasing interest in Syria may have been based on a notion of achieving positive results with the West. Being aware of the planned Crusade, Abaqa dispatched envoys in early 1267 to Pope Clement IV (1265-1268) and to James I of Aragon (1213-1276). ${ }^{166}$ In his reply to the Pope in 1268, Abaqa Khan agreed to send troops under the command of his brother Ejei (Hegei/Adjai) to aid the Eighth Crusade. ${ }^{167}$ The recent fall of Antioch to Baybars in 1268 had forced Abaqa to make several decisions. In September 1271, after unsuccessful attempts to meet Louis IX (r. 1226-1270) in 1268 and 1269 and Philip III (r. 1270-1285 in 1270, Abaqa asked Lord Edward, the future King Edward I of England, to undertake simultaneous actions against the Mamluks. ${ }^{168}$ Edward, who arrived in Palestine with a contingent insufficient to carry on the crusading tradition, may have realised that the West needed to ally with the Mongols. ${ }^{169}$ He sent his envoys, Reginald Russell and John Parker, to Abaqa in order to arrange for joint military action against Baybars. ${ }^{170}$ These actions, however, took place with no result for either side. ${ }^{171}$ Despite the failure of military collaboration with Edward's crusade, Abaqa continued his policy to drive out the Mamluks from Syria by continuously appealing to the Latin powers. In 1273, he once more wrote letters both to the Pope and to Edward I of England. Abaqa's envoys, David of Ashby, the papal legate in Palestine and Abaqa's Latin inter-

164 Meyvaert, 1980:245-259; Jackson, 2005a:166.

165 Thorau, 1992:193-196.

166 Lupprian, 1981:220-225; Jackson, 2005a:167.

167 Jackson, 2005a:167.

168 Ibid., 167; Richard, 1983:34-35.

169 Dawson, 1955:xxvii. Edward lacked manpower. According to Smbat Sparapet, King Edward came to Acre by boat with 2,000 men (Der Nersessian, 1973:376).

170 Dawson, 1955:xxvii. Baybars commissioned his agent to arrange for Edward's murder. On the pretext of seeking baptism, a certain Assassin was deployed. According to the Armenian chronicle, Edward was stabbed five times, but recovered from the dagger wounds (King Het'um II, 1962:74). Immediately after this failure, Baybars sent an embassy to Edward expressing his regret at the attack and denial of his involvement (Thorau, 1992:221-222).

171 Abaqa was involved in the war with the Chaghatai Khanate (Richard, 1976:43-54). 
preter Richardus repeated the message at the Council of Lyons, summoned by Pope Gregory X (1271-1276) in 1274 in order to plan a new crusade. ${ }^{172}$

Despite being invited neither Armenians from Cilicia, nor from Greater Armenia were present at this Council. ${ }^{173}$ Scholars consider that during the period of the Mongol-Armenian alliance, especially from 1260 to 1288, the Armenian Church became less susceptible to the demands of Rome. Having gained security from association with the powerful Mongols, the Armenian Church felt no need to remain in union with the Church of Rome and thus it declined to be present at the Council of Lyons. ${ }^{174}$ This also explains the bold assertion of Mkhit'ar Skewrats'i, at the meeting at Acre with the Pope's legate, Bishop John of Jerusalem, about Armenian ecclesiastical independence from Rome. Mkhit'ar Skewrats'i questioned why the Church of Rome had the authority to judge other apostolic sees and why it could not be judged by others, and since the Armenians had full powers to judge Rome, the Roman Church could not criticise them for doing this. ${ }^{175}$ Undeniably, this argument played a crucial role in the deterioration of the good relationship between the Roman and Armenian Churches; however, it was clear that Mongol backing emboldened the Armenian Church. ${ }^{176}$

In 1275, the Mongol ambassador David of Ashby visited King Edward I and in 1277, he was in Italy. ${ }^{177}$ Abaqa received no positive reply from either the Papacy or from France or England. Since Abaqa had not succeeded in eradicating the Mamluks with the help of the West, he decided to act alone. In 1277, Baybars I died at Damascus on his way back from the invasion of the Seljuks of Rūm. ${ }^{178}$ Having been defeated by the new Sultan Qalāwūn (r. 678-689 H. / 12791290), Sunqur, a former prisoner of the Mongols, wrote Abaqa a letter informing him of the disunity within the Sultanate and offering the Khan his help in invading Syria. ${ }^{179}$ According to Arabic sources, in the Summer of 1280, Abaqa sent his brother Möngke-Temür, a

${ }^{172}$ Lupprian, 1981:226-230; Roberg, 1990:285-286; Richard, 1976:46-57.

173 Pogossian, 2006:288.

174 Bundy, 1996:39; Pogossian, 2006:288.

175 RHC, Arm, 1, 691-698.

176 Bundy, 1996:39.

177 Jackson, 2005a:168.

178 Amitai-Preiss, 2004:177-178.

179 Ibid., 182. 
young and inexperienced commander, to Syria. ${ }^{180}$ Möngke-Temür entered Syria with a large army and reached as far as Aleppo. ${ }^{181}$ Before sending his last embassy to Edward I, in 1280, Abaqa had demanded that Latin military forces and provisions be supplied from Acre. ${ }^{182}$ Only the Cilician Armenian King Lewon III joined him with his troops, along with Bohemond VII of Tripoli. The Latin West was represented by some Hospitallers from Margat (Marqab). ${ }^{183}$ Sultan Qalāwūn left for Syria in November 1280 and positioned his army between Möngke-Temür and the Franks on the coast. ${ }^{184}$ Reaching Gaza, the Sultan was informed that Möngke-Temür had looted the city and had withdrawn from the country. Qalāwūn decided to go back to Egypt. ${ }^{185}$ The notion of the desecration of Muslim sanctuaries by the Cilician Armenians is again found in Arabic sources. According to Mufaḍdal, the Great Mosque of Aleppo was set on fire by the Armenians of Sis. ${ }^{186}$ As has been said before, the first burning of the Great Mosque was attributed to King Het'um I in 1260. ${ }^{187}$

In September 1281, Möngke-Temür along with Generals Alinaq, Taiju-Bahadur, Tukna and Doladai headed for Syria again. ${ }^{188}$ Abaqa Khan set out after Möngke-Temür a month later and reached Erznka, where he was informed that the army of the Golden Horde had passed the Derbent Gate, so he hurried home without helping his brother. ${ }^{189}$ The Mongol army of 50,000 Mongols and 30,000 Armenians, Georgians, Franks and Seljuks marched through Abulustayn and reached as far as 'Ayn TTāb. ${ }^{190}$ The battle with the Egyptians took place near Homs on 29/30 October. ${ }^{191}$ King Lewon commanded the Mongol right wing, comprised of Armenians and Georgians. ${ }^{192}$ They

\footnotetext{
${ }^{180}$ Ibid., 183.

181 Amitai-Preiss, 2004:184.

182 Jackson, 2005a:168.

${ }^{183}$ Ibid.

${ }^{184}$ Ibid.

185 Amitai-Preiss, 2004:185.

186 Stewart, 2001:54.

187 See Chapter 5.

${ }_{188}$ Rashīd al-Dīn, 1954:778.

189 Sebastats'i in Hakobyan, 1956:147.

190 Stewart, 2001:54. It is 30,000 men in total in Het'um Patmich', 1951:57.

${ }_{191}$ On the battle formation, size of the armies and losses, see Amitai-Preiss, 2004:187-201.

${ }^{192}$ Het'um Patmich', 1951:58. The Georgians were commanded by Dimitri (King Demetrē, 1270-89) (Amitai-Preiss, 2004:189).
} 
drove back the left wing of the Egyptians to the gate of Homș. ${ }^{193}$ Nevertheless, in the centre, Möngke-Temür was wounded and turned back with the greater part of his army to Upper Mesopotamia. The Armenian King was surprised that Möngke-Temür left the battlefield but he followed him, being mercilessly attacked by the Mamluks. It caused him to lose more than 2,000 men. ${ }^{194}$ Besides the Cilician Armenians, according to Step'annos Orbelian, among the Mongol troops were the forces of Greater Armenia under the command of Tarsaich Orbelian and they fought in this and previous Mongol battles for Syria. ${ }^{195}$

News of the Mongol defeat reached Abaqa in Mosul (al-Mawsil), ${ }^{196}$ and disappointed him greatly. He decided to avenge his brother's defeat the next year. He set out for Hamadān and arrived there on 18 March 1282, where after a heavy drinking bout that later would be considered an assassination, he died on 1 April $1282 .{ }^{197}$ He was laid to rest alongside his father on the island of Shāhī. ${ }^{198}$

Abaqa's period can be justly identified as the high point of the Mongol-Armenian military relationship, where both parties played a keen role in assisting each other to take over Northern Syria, pursuing not similar, but common goals. After this, Mongol-Armenian relations were maintained through diplomacy, rather than through joint military actions.

\section{Mongol-Armenian Relations in the Time of Tegüder Ahmad (r. 1282-1284)}

After the death of Abaqa Khan, Western rulers learned that Mongol power in the Middle East was now held by one who was less favourable to the Christians. After Möngke-Temür died, the candidacy for the next Il-Khan was discussed widely among the descendants of Hülegü. Tegüder, Hülegü's son, the younger brother of Abaqa Khan,

${ }^{193}$ Het'um Patmich', 1951:58.

194 Ibid., 58-59; King Het'um II, 1962:75.

195 Step'annos Orbelian, 1910:423.

${ }_{196}$ From 660 H. (1272), Mosul became a finance and trade centre of the IlKhanate with the south-west (Kolbas, 2006:166).

197 An Armenian source attributes Abaqa's death to poison, given by the Mamluks when the Mongol Il-Khan was planning to fight against the Egyptians (Het'um Patmich', 1951:59).

198 Rashīd al-Dīn, 1954:779. 
and the governor of Kurdistān had more support and a more powerful position than Abaqa's eldest son Arghun. ${ }^{199}$ On 6 May 1282, Tegüder's proclamation took place at Ala-Tagh. According to Het'um Patmich', Tegüder 'in his childhood had been baptised and called Nicholas ( (hlinnuunu), but later, being acquainted with the Saracens whom he loved, he became a Saracen and wanted to be named as Mahomet Khan. He tried with much effort to convert the Tatars to the faith of Mahomet. ${ }^{200}$ As a convert to Islam, he was not only named Ahmad after the dervishes of the Ahmadiyya sect, but also given the title of Sultan. ${ }^{201}$ An alternative point of view can be ascertained from the sources not only in the details of his conversion, ${ }^{202}$ but also in his policy towards the Muslims and the Christians. According to Het'um Patmich', Tegüder (Ahmad) pursued an antiChristian policy, ordering the destruction of the Christian churches in Tabriz and forcing all Christians to adopt Islam. For this reason, the Armenians experienced terrible persecution. ${ }^{203}$ From this period onward, the cases of people during the Mongol period lamenting over their sins is augmented in the Armenian sources. In connection with this view, Lane states that the evidence of the Armenian chroniclers appears to be a sectarian interpretation by an isolated and threatened minority group of Christians (Armenians). ${ }^{204}$ This statement sounds reasonable for the Armenian anti-Christian portrayal of Tegüder; however, it is contradicted by Bar Hebraeus. The Syriac source depicts Tegüder as merciful to those of the Christian faith, as one who issued decrees to free all churches, religious houses and priests from the imposition of taxes in the lands under the Mongols. ${ }^{205}$ These opposing statements by the Christian sources may reflect not only the Armenian response to the Il-Khan's conversion, but also Tegüder's ambivalence in the matter of his faith, and can be contrasted with the opinion of Reuven Amitai, who emphasises that

199 Rashīd al-Dīn, 1954:785.

${ }^{200}$ Het'um Patmich', 1951:59. The Armenian historian may mean the rise of Shaikh Kamāl al-Dīn 'Abd al- Rahmān at Abaqa's court and his influence on the minor Tegüder and his mother, which is discussed by Amitai, 2001:21.

${ }^{201}$ Rashīd al-Dīn, 1954:785.

202 According to the Mamluk sources, Tegüder had become a Muslim first and then he ascended the throne, unlike the other Mongol converts (Amitai, 2001:1822).

${ }^{203}$ Het'um Patmich', 1951:59-60; Step'annos Orbelian, 1910:425.

204 Lane, 2003:56.

${ }^{205}$ Bar Hebraeus, 2003:467. 
Tegüder's early conversion 'had nothing to do with a mature person's crisis of faith. ${ }^{206}$ Probably at that time, neither Tegüder, nor the Mongol court in Iran completely realised the full responsibility and consequences of their actions. Tegüder was the first Mongol Muslim ruler in Iran and made his religion a public matter. ${ }^{207}$ His religious ambivalence is shown from research on the coinage during his reign. Tegüder minted a coin in Tiflis in 1282 with a Trinitarian Christian inscription in Arabic, In the name of the Father and the Son and the Spirit, Holy God is one. ${ }^{208}$

The Armenian work of Step'annos Episkopos asserts that after Tegüder (Ahmad) had changed his title of Khan to Sultan, senior positions at his court were given to the Persians. ${ }^{209}$ The office of șâhib-dìvān was a key position in the echelons of power in the Il-Khanid Empire. Șạhị-dīvān Shams al-Dīn Juvaynī, who served Abaqa and later his son Arghun, first transferred his service to Tegüder. Shams al-Dīn became a major source of conflict that had already existed between Arghun and Tegüder from the very first day of the latter's proclamation. The Juvayni brothers were accused of being in league with the Mamluks and Shams al-Din was blamed for the misuse in Abaqa's time of huge sums from the royal treasury. Later, he was charged with administering poison to Abaqa Il-Khan. ${ }^{210}$ Arghun believed this accusation. However, Tegüder not only restored Shams al-Dīn Juvaynī as șăhib-dìvān, but also followed his advice to open negotiations with the Sultan of Egypt. ${ }^{211}$

Interestingly, Tegüder's first message to the Sultan dated midJumada I 681 (22 August 1282), was far from being a call for an alliance; it was an ultimatum of the Mongol Il-Khan, who urged Qalāwūn to show submission in order to secure his sovereignty. ${ }^{212}$ In his reply to Tegüder, the Sultan expressed his readiness to make peace with conditions to be discussed later, ignoring the issue of submission. ${ }^{213}$ In his second message to Qalāwūn dated at the begin-

\footnotetext{
206 Amitai, 2001:22.

${ }^{207}$ Ibid., 15.

${ }^{208}$ Kolbas, 2006:238.

209 Step'annos Episkopos, 1951:45.

${ }^{210}$ Rashīd al-Dīn, 1954:786.

${ }^{211}$ Ibid., 788. Tegüder was the first among the Il-Khans to initiate negotiations with the Sultan to end the Mongol-Mamluk conflict (Amitai, 2005:360).

${ }^{212}$ Jackson, 2005a:169; Allouche, 1990:438. On the tone of Tegüder's letter to Qalāwūn as an equal, rather than as a subordinate, see Pfeiffer, 2006c:185-187.

213 Allouche, 1990:441.
} 
ning of Rabīi I 682 (May-June 1283), Tegüder omitted words of obedience and submission and spoke only about peace and an agreement between the Il-Khans and the Mamluks. ${ }^{214}$ When the envoys arrived in Damascus in February-March 1284, with the message from Tabriz, the news of the death of Tegüder (Ahmad) and the accession of his rival nephew Arghun reached Qalāwūn. ${ }^{215}$

Tegüder's policies with the Mamluks met serious opposition from the Mongol elite in Iran and Anatolia. ${ }^{216}$ Arghun began his open rebellion against Tegüder (Ahmad) in the Spring of 1283. If we believe Het'um Patmich', Arghun turned to Qubilai Khan to complain about Tegüder. Qubilai Khan warned Tegüder that he himself would come up against him if he did not pull back. ${ }^{217}$ According to this statement, and what is mentioned by Step'annos Orbelian and Sebastats' $i$, the Armenians supported Arghun. ${ }^{218}$ Tegüder employed his son-in-law, the Georgian General Alinaq (Alinakh) against Arghun. The Georgians might mistakenly have seen their chance to gain political authority through Tegüder. According to Kolbas, from 1282, the equal number of coins struck in Tiflis and in Tabriz shows the growing influence of the Gurjistan area in Tegüder's time. ${ }^{219}$ Alinaq arrested Prince Qongqurtai, the younger half-brother of Tegüder, a supporter of Arghun; moreover, he imprisoned Arghun in July $1284 .{ }^{220}$ According to Sebastats'i, Tegüder killed not only his brother Qongqurtai, but also many Mongol nobles, Georgian lords and the Seljuk Sultan Ghiyāth al-Dīn, the son of Rukn al-Dīn, in the same year 1284. ${ }^{221}$ The other Armenian sources describe Tegüder killing many others, including the two sons of Tsagan, the great governor of Georgia. ${ }^{222}$ To judge from these accounts, one can see that the Georgians' inclination towards Tegüder turned out to be detri-

214 Ibid., 443.

215 Ibid. On Aḥmad Tegüder's second letter to Qalāwūn, see Pfeiffer, 2006c:167197.

${ }^{216}$ Allouche, 1990:438-90; Pfeiffer, 2006c:185-188. In 1284, he executed his younger brother Qongqurtai, on a suspicion of conspiring against him in concert with Arghun (Amitai, 2001:15).

${ }^{217}$ Het'um Patmich', 1951:60.

218 Step'annos Orbelian, 1910:425; Sebastats'i in Hakobyan, 1956:148.

${ }^{219}$ Kolbas, 2006:236.

220 Step'annos Episkopos, 1951:46.

221 Sebastats'i in Hakobyan, 1956:148.

222 Step'annos Orbelian, 1910:425; Step'annos Episkopos, 1951:46. 
mental to them. As has been said above, Armenian interests lay with Arghun.

In addition to this, the amirs and princes of the House of Hülegü were displeased with Tegüder's actions. Amir Bugha, who was secretly in sympathy with Arghun, released the latter and killed Alinaq, as well as all of Tegüder's supporters. ${ }^{223}$ In return, Tegüder reached Qongqur-Öleng (Sultaniyya), Bugha's ordu and looted it. In his own ordu in Songhurluq at Shīz (Takht-i Sulaymān), he prepared to reach the Derbent gate and escape to the territory of the Golden Horde. However, he was arrested and brought to the Chinggisid family trial, being accused of the execution of Prince Qongqurtai. Tegüder's death sentence was carried out on 10 August $1284 .{ }^{24}$ With the elimination of Tegüder, the Mongol-Armenian alliance recovered itself with another strong partnership of rulers.

\section{The Second Pairing of Arghun and King Lewon III against Sultan Qalāwūn}

Arghun's reign was well regarded in both Cilician Armenia and Greater Armenia. According to Step'annos Orbelian, the Houses of Zak'arian, Artsruni and Orbelian along with the Georgian King Demetrē (r. 1270-1289) were fully in support of Arghun. ${ }^{225}$ He was enthroned on 11 August 1284, the day after his predecessor's execution, on the banks of the river Shür in the presence of the khatuns, amirs and some princes. ${ }^{226}$ It seems that, in order to maintain a firm hold over his domain, Arghun was engaged with executions and new

223 Rashīd al-Dīn, 1954:790-98.

224 Ibid., 798-800. Step'annos Episkopos states that Tegüder tried to escape by changing into female dress; however, he was caught, tortured and killed (Step'annos Episkopos, 1951:47). Tegüder was killed in the same way as he executed Qongqurtai, his half brother, through the breaking of his back, the location of his tomb is not known (Vașșaf, 1856:278[trans. 261]).

225 Step'annos Orbelian, 1910:426.

226 Rashīd al-Dīn, 1954:807. The official sanction for Arghun's accession to the Il-Khanid throne came later on 7 April 1286, from Qubilai Khan. For this reason, the second quriltai was summoned (Rashīd al-Dīn, 1954:812). Eliminating Tegüder, Arghun aimed to bring Anatolia directly under his control. He sent his brother Geikhatu and uncle Hulachu to Rūm as governors in 1284 (Sebastats'i in Hakobyan, 1956:148). His son Ghazan was sent to the provinces of Khurasan, Mazandaran, Qūmis and Ray along with Nawruz, whose duty was to support Ghazan as Amir of Khurasan, while his uncle Adjay was sent to Gurjistan vilayet (Rashīd al-Dīn, 1954:808). 
appointments. Arghun ordered the execution of Ebügen, the son of Shiramun, the grandson of Chormaghan, and Tegüder Ahmad's protégé. ${ }^{227}$ Then Shams al-Dīn, the deputy to vizier Bugha, was executed in October 1284. ${ }^{228}$ Bugha himself became a victim of the internal conspiracy within the Il-Khanid court and being betrayed by Jüshkeb, Arghun's cousin, was put to death on January $1289 .{ }^{229}$ His office was given to Sa'd al-Daula, a Jewish physician. But in March 1291, he also was executed. ${ }^{230}$

The death sentences continued in Georgia as well. The Georgian King Demetrē, the son of David Ulu, who reigned over the eastern part of Georgia, and actively participated in Abaqa's campaign against the Mamluks between 1277 and 1281, was a true vassal of the Il-Khans. He played a great part in subduing the rebels in Derbent (provoked by the Golden Horde) in 1288 on the order of Arghun Khan. However, Arghun discovered the plot allegedly organised by Bugha. ${ }^{231}$ According to Step'annos Orbelian, Arghun falsely suspected the involvement of Demetrē in this intrigue only because he was married to Bugha's daughter. ${ }^{232}$ Demetrē was killed on the plain called $U$ nıцlqui (Mughan) on the bank of the river Kur in 1289. ${ }^{233}$ The sources are open about the persecution of the Georgians but say nothing about the Armenians. A reason for this could be that the Armenian lords were personally closer to the Il-Khans, rather than to the Georgian crown. They also helped the Il-Khans find a proper candidate for the Georgian throne. Hence, with the assistance of Khutlu Bugha, the son of the Armenian Lord Sadun Artsruni, Arghun enthroned Vakhtang II (r. 1289-1292), the grandson of Rusudan, as

${ }^{227}$ Ibid. On 7 September 1296, the other son of Shiramun was executed (Rashìd al-Dīn, 1946:171).

${ }^{228}$ Rashìd al-Dīn, 1954:811.

${ }^{229}$ Ibid., 817-18; Aubin, 1995:40-44. In 1286, Bugha was honoured with the title of Chink'san[k] (from Chinese ch'eng hsiang [chancellor]) bestowed by the Great Khan (Rashīd al-Dīn, 1954:812; Allsen, 2001:28.

${ }^{230}$ Rashīd al-Dīn, 1954:825.

231 The Greater Armenian poet Frik in his poem About Arghun Khan and Bugha was very explicit in showing his sympathy towards Arghun. According to him, Arghun, the Chinggisid son was chosen by God, who cannot be beaten by anyone (Frik, 1941:209-215, 1952:422-223).

${ }^{232}$ King Demetrē II practised polygamy by marrying three wives; the second was a Mongol princess named Songur, a daughter of Bugha Chink'san[k]. He had three children by this Mongol wife, one of whom, a princess called Jigda, was given in marriage to Alexius III of Trebizond (1338-1390).

233 Step'annos Orbelian, 1910:430. 
the Georgian king. The latter appointed Khutlu Bugha Artsruni as the uuquuulup (general) of the Georgian army. ${ }^{234}$ While the Georgians were mistreated, the Armenians in Greater Armenia profited. It was Tarsaich Orbelian who succeeded in eliminating from the royal tax registry about 150 Armenian monasteries and convents, which was confirmed again by Arghun's decree in $1287 . .^{235}$ In 1290, after the death of Tarsaich, Arghun solved the dispute among Tarsaich's sons over their father's succession and appointed Elikum Orbelian as atabeg of the Armenians. ${ }^{236}$

Placing Georgia and Armenia under his direct control, Arghun successfully defended his realm from the brief incursions of TöleBuqa (r. 1287-1291) in 1288 and of Toqta (r. 1291-1312) of the Golden Horde in $1290 .{ }^{237}$ But another danger to Arghun came from the rebellion of Nawruz, the son of Arghun Aqa, who was sent as the military governor to Khurasan along with Ghazan, the son of Arghun Il-Khan. ${ }^{238}$ According to Step'annos Episkopos, Ghazan fled from Nawruz, while Arghun sent a large force to suppress the rebels. ${ }^{239}$ The rebellion of Nawruz lasted for five years from 1289 to 1294 and kept Arghun busy concentrating on local matters. ${ }^{240}$ However, the Armenians did not lose the opportunity to remind him about their mutual affairs.

As has been mentioned earlier, the Armenian King Lewon III visited Arghun in 1285. He was well received by the Mongol Il-Khan. ${ }^{241}$ However, Mongol foreign policy turned out to be harmful to the Cilician Armenians. Arghun employed 800 Genoese in building ships at Baghdad as a result of his first appeal for joint Mongol-Latin operations. He aimed to take from the Egyptians their trade in the Red Sea. ${ }^{242}$ In revenge, Sultan Qalāwūn raided and pillaged the Cilician Armenians in 1285.

Arghun's relation with the Cilician Armenians brought much dissatisfaction. In 1285, Lewon was forced to sign a ten-year treaty with

\footnotetext{
234 Step'annos Episkopos, 1951:49. Persian sepahsālār (commander-in-chief).

235 Step'annos Orbelian, 1910:427, 429.

236 Ibid., 430-431.

237 Rashīd al-Dīn, 1954:821-822; Boyle, 1968:370.

238 Rashīd al-Dīn, 1954:819; Melville, 1995:56.

239 Step'annos Episkopos, 1951:50.

240 Boyle, 1968:370; Melville, 1995:56-57.

241 Sebastats'i in Hakobyan, 1956:148.

242 Jackson, 2005a :169.
} 
Cairo at the high cost of an annual tribute of one million dirhams. ${ }^{243}$ This agreement gave Cilicia relative peace and allowed Lewon to concentrate his attentions on improving the living conditions of his people. He started to rebuild Sis and its monasteries, to safeguard trade and pilgrimage routes, to increase commerce and market revenues in Ayas, which helped Lewon to meet the heavy tributes levied by the Mamluks. ${ }^{244}$

The reign of Lewon III was marked by a number of invasions into Cilician Armenia by the Mamluks and by Turkomans and Kurdish bandits ${ }^{245}$ Lewon's hopes lay again in the Mongol alliance; however, little assistance came from it. The Mamluks, now under the Sultan Qalāwūn, having won the neutrality of the Franks, completely destroyed the allied forces. Lewon died in 1289 and was succeeded by his eldest son Het'um II (r. 1289-1293; 1295-1297; 1299-1305; joint ruling 1305-1307), who would experience more troubles caused by his having too many ambitious brothers. ${ }^{246}$

In order to resolve the Mamluk-Mongol war, Arghun continued his father's policy of seeking an alliance with the Franks. He sent four missions to the Latin West; some were undertaken jointly with the Armenian monarch. The first was in 1285, accompanied by Qubilai's envoy called 'Îsā Kelemechi, sent to Pope Honorius IV (1285-1287). ${ }^{247}$ In the letter, it was proposed to divide the land of Egypt between Arghun's dominions and the West. ${ }^{248}$ In 1287, the second embassy led by Rabban Șawma, a Nestorian prelate from

${ }^{243}$ Boase, 1978:28; Der Nersessian, 1973(I):349. The treaty was signed to last for ten years, ten months and ten days. In addition to the annual tribute, Cilicia was obliged to supply 25 pedigree horses, the same number of mules and 10,000 iron bars for horse-shoes along with nails (Mikaelean; 1952:414; Langlois, 1862:217-231, Canard, 1967:217-259). The text of this treaty given by 'Abd al-Zāhir in Tashrîf (93102) is translated into English (see Holt, 1995:95-103). A dirham was a silver coin, six dirhams were equal to one dinar or golden coin (Feodorov-Davydov, 2003:3033).

${ }^{244}$ Mikaelean, 1952:415. The financial condition of the clergy improved. Historiography flourished, as Lewon's secretary, Vahram, left a detailed account of Cilician history and contemporary events. For details, see Vahram, 1831.

${ }^{245}$ Turkomans provided constant internal disruption to the Mongols in Anatolia as well (Melville, 2009:51-101).

246 Stewart, 2001:65. Lewon was married to Queen (Ker) Ann, and they had seven sons and four daughters. Rüdt-Collenberg states that Lewon and Ann had 14 children (Rüdt-Collenberg, 1963:32). Het'um II was married to the daughter of Hugh III of Cyprus (r. 1267-1284) (Mikaelean, 1952:416).

247 Lupprian, 1981:245-246.

248 Jackson, 2005a:169. 
China set out for Europe. ${ }^{249}$ They returned the next year bringing letters from the newly-elected Pope Nicholas IV (1288-1292), Edward I of England and Philippe le Bel of France full of assurances of support but no promise of actual assistance. ${ }^{250}$ In 1289-1290, another mission was sent by Arghun to the Pope, and the Kings of England and France. In reference to these events, Step'annos Episkopos states that in the same year, the renowned emissaries of the Pope visited Arghun and built an expensive church at his Court, which was consecrated. ${ }^{251}$ Arghun initiated another mission, which carried letters to Rome from the next Armenian king Het'um II, proposing a Mongol-Rome-Armenian alliance against the Mamluks. ${ }^{252}$ The last emissaries arrived in the Summer of 1290 and brought to Arghun in 1291 the reply from Pope Nicholas IV, who, after learning that Acre, the last Frankish-held stronghold in Palestine, had fallen, urged the Il-Khan to be baptised and to move against the Mamluks. ${ }^{253}$ Arghun had already died by that time, and the Pope himself died in the following year, without managing to instigate the crusade. ${ }^{254}$

The Il-Khan Arghun's reign was another chance for the Armenians to implore the Mongols to free the Holy Land. Although Arghun accepted this idea, he could not fulfil his promise during his reign. His monetary reforms to increase the weight of coins, the regulations of their minting cycles, and the use of subsidiary coinage for the payment of foreign trade were dictated by the stability of the financial system in his realm. ${ }^{255}$ Arghun was interested more in science, alchemy, building and treatments for longevity. He tried many alternative medicaments on himself: Indian, Jewish and Muslim. ${ }^{256}$ Eight months of consuming a mercury-based elixir made him chronically

${ }^{249}$ This time Sawma was accompanied by ‘Saabedin' who later visited Europe as part of the embassies of 1290 and 1302 (Jackson, 2005a:173). This 'Saabedin' might be the same Sahmaddin, an Armenian merchant who owned vast lands rich in orchards to the south-west in Greater Armenia, near to caravan routes (Mikaelean, 1952:422; Khachikyan, 1958:104).

${ }^{250}$ Budge, 1928:165-197; Rossabi, 1988:152.

${ }^{251}$ Among those who consecrated the church, there were the Nestorian catholicos from Baghdad along with 12 Armenians, and the Episkope from Varag monastery (Step'annos Episkopos in Hakobyan, 1951:50).

${ }^{252}$ Bundy, 1987:227-228; Golubovich, 1906(1):301-306, 1906(2):440; K'evorkian, 1996:188-195; Mutafian, 1999.

${ }^{253}$ Lupprian, 1981:270-276.

254 Jackson, 2005a:169.

${ }^{255}$ For the monetary reforms of Arghun, see Kolbas, 2006:245-256.

${ }^{256}$ Rashīd al-Dīn, 1954:821, 823. 
ill. Learning that the Il-Khan's life was in danger, the amirs' mutual hostility was increased and they started to form a conspiracy to eliminate each other. Disorder and outrages took place in Tabriz and Baghdad. ${ }^{257}$ Arghun died on 10 March 1291 in Arran. ${ }^{258}$ His partnership with Lewon III did not bring any of the desired results. Instead, the Armenian kingdom became a tributary to the Mamluk Sultan. Although Sultan Qalāwūn was not as aggressive as Baybars, his constant raids on Cilicia served to put the Armenians under economic pressure.

\section{The Weakest Link: Het'um II and the Mongol Il-Khans: Geikhatu (r. 1291-1295) and Baidu (1295)}

After the deaths of Arghun Il-Khan and King Lewon, the Mamluk policy became more aggressive towards the Il-Khanate and Armenia. The reason for this was the succession of the very ambitious and energetic Mamluk Sultan al-Ashraf Șalāḥ al-Dīn Khalī (r. 689-693 H. / 1290-1293), the son of Qalāwūn, and of feeble candidates as rulers in the Il-Khanate and Cilician Armenia. Het'um's vacillations between the throne and the monastery allowed some scholars to conclude that he was 'little suited to the times. ${ }^{259}$ The Mongol noyans, amirs and their supporters, who summoned a quriltai held near Akhlāt on 23 July 1291 (24 Rajab 690), had a choice of three candidates for the next Il-Khan, and chose unwisely. As stated above, Arghun's son Ghazan was in Khurasan. His brother Geikhatu (Gaikhatu) was in Rūm and his cousin Baidu in Baghdad. ${ }^{260}$ The main focus was on the brothers of Arghun, rather than on his son. Geikhatu's supporters were stronger than Baidu's, so he was proclaimed as Il-Khan. ${ }^{261}$ Geikhatu was known more for his failure in an innovative monetary policy, rather than for his political activities. The introduction of Chinese paper money called chäo to replace the

257 Ibid., 825.

${ }^{258}$ Ibid., 825. According to Sebastats'i, Arghun Khan was poisoned along with his șāhịib-dīvān Sa'd al-Daula (Sebastats'i in Hakobyan, 1956:149).

259 Boase, 1978:29.

260 The Buddhist name of Geikhatu or Gaikhaltu (which means 'remarkable' in Mongolian) was Irinjin Dorji or Rintsen Dorji (Rashīd al-Dīn, 1954:829); it was used on the silver coins minted in Tabriz in 693 H. (1294) (Kolbas, 2006:279).

261 Rashīd al-Dīn, 1954:830. 
metallic currency in Tabriz on 19 Shawwal 693 (12 September 1294), in order to overcome economical difficulties, proved a fiasco. ${ }^{262}$

Information about Geikhatu (ntquuhqu) is very obscure in Armenian sources. Some describe him as a man who had neither laws, nor faith. ${ }^{263}$ The debauchery of Geikhatu, which is found in Rashīd al-Dīn and in Vașșaf, is noted by Het'um Patmich' and by the continuator of Bar Hebraeus. ${ }^{264}$ Sebastats'i records only that Geikhatu (furjnuinnz) caused much destruction in a place called Tongozlu in 740 Arm. (1291). ${ }^{265}$ Arabic sources also do not have a high opinion of Gaikhatu. ${ }^{266}$

According to the Chronicles of King Het'um II, during the reign of Geikhatu there were many occasions when the Mamluk Sultān al-Ashraf Khalil (r. 1290-1293) had attacked the coastal castles of the crusaders, such as those at Acre, Tyre and Beirut, and the cities in the privileged trading area on the right bank of the Euphrates in 1291, forcing the Christians to flee. ${ }^{267}$ The Mamluks of Egypt decided to drive out the crusaders once and for all, and to eliminate the Franks from the region. ${ }^{268}$ Letters were exchanged between Geikhatu and al-Ashraf, when the war began to escalate again. ${ }^{269}$ In addition to this, three different letters were registered which were received by Edward I in 1291. The first one was from Het'um II on the fall of Acre to the Mamluks and on the Armenian appeal for aid to the crusades. ${ }^{270}$ The other two were the letters of Sultān al-Ashraf Khalil to Het'um forwarded to Edward. ${ }^{271}$ The content of these letters was probably about the Mamluk supremacy and threats to Cilician Armenia in connection with the fall of Acre and Tyre. ${ }^{272}$ In any case, these letters testify to the unpromising situation in Cilician Armenia.

In fact, the Mamluks' raids throughout Cilicia were directly linked with the weak position of King Het'um II, who repeatedly abdicated. The Armenian monarch often sought refuge in the church, first in

262 Ibid., 835.

263 Het'um Patmich', 1951:62.

264 Ibid., 62; Bar Hebraeus, 2003:494.

265 Sebastats'i in Hakobyan, 1956:149.

266 Abu'l-Fidā'; 1983:24; Stewart, 2001:68.

267 Galstyan, 1962:76; Hakobyan, 1956:79.

268 Mikaelean, 1952:416.

269 Al-Maqrīzī, 1934-1974(I):786; Amitai, 2005:361.

270 Lloyd, 1988:251.

271 Ibid., 251-252.

272 Ibid., 251-52; Stewart, 2001:67. 
the monastery he had built at Mamistra and later by becoming a friar called John in a Franciscan church. ${ }^{273}$ The Papacy was active in sending Franciscan missions to Cilicia. ${ }^{274}$ Het'um II entered into diplomatic contacts with the Papacy. Het'um sent an embassy of four people to the Pope on the matter of the Holy Land in 1292. Nicholas IV sent them on with letters of commendation to Edward I of England. There was also a letter sent by Nicholas IV to 'all the faithful' about oppression in regions of Cilician Armenia in 1292. ${ }^{275}$ However, just as Byzantine rulers had tried to force Greek Orthodoxy on the Armenians, the Papacy, in return for their help, required the Armenians to accept Catholicism. ${ }^{276}$ Some nobles and ecclesiastics in Cilicia converted to Catholicism, which led to a rift between the episcopacy in the Cilician Kingdom and in Greater Armenia. ${ }^{277}$

In order to end pro-Latin and anti-Latin conflicts within his realm and to deal with the Mamluks himself, Het'um II tried to appease the Egyptians by offering large sums of money. In 1292, Sultan alAshraf seized Hromklay (Qal'at al-Rüm in Arabic), the See of the Armenian Catholicos, which was a very strongly fortified place on the bank of the Euphrates. ${ }^{278}$ According to an Arabic source, the Cilician monarch tried to relieve the defenders of Hromklay. He dispatched a cavalry force of 5,000 men, dressed as Mongols, to halt the Mamluks. ${ }^{279}$ The Armenians wore Mongol hats (sarāqūjāt), imitating the Mongols, to attack the caravans. ${ }^{280}$ When al-Ashraf found that it was a false Mongol raid, he sacked the citadel. The Armenian chronicler of the fourteenth century Nersēs Palients' details the siege of Hŕomklay:

In the Armenian year 741 (1292), the Egyptian Sultan Ashraf after he had captured and destroyed Ak'a [Acre] nearly wiped out all Christian lords and even their names from the Holy Land and from the coastal area. Afterwards this evil dragon embarked upon the Armenians, and moved with the army to Mesopotamia closer to the border of the city of Uriha [Edessa]. He surrounded the fortress of the Armenian Patriarch that was called the Castle of Hromklay, where the see of the Arme-

\footnotetext{
273 Crawford, 2003:137.

${ }^{274}$ Der Nersessian, 1969:50.

275 Lloyd, 1988:255, 259.

276 Mikaelean, 1952:417.

277 Der Nersessian, 1969:50.

278 Abu'l-Fidā'; 1983:18-19.

279 Stewart, 2001:78.

280 Amitai-Preiss, 2004:132.
} 
nian Patriarch existed for a long time. The Sultan besieged it [severely] with constant force so that the Christians could not defend it, because the Armenian King sent his maternal uncle there, the Baron Raymond ( $R$ tunnin) along with numerous elite men. The Tajiks did not manage to take the fortress despite fighting for many months.

... The Armenian Catholicos, Ter-Step'annos, surnamed Hŕomaets'i, who was inside the fortress, finding no means [to survive] put on his patriarchal robe, the same as the other bishops, and with the crosses and with holy relics they went to the feet of the Sultan. People say that when the tyrant saw this, he spat on the Catholicos, saying: 'Why did you not do this on the first day?' Since they themselves came to him, the order was given to kill no-one. In this manner, the same Sultan took Hromklay on the same day. The Catholicos along with all the Christians, more than 30,000 people, were taken into captivity to Egypt as prisoners and as slaves. ${ }^{281}$

Het'um II freed the Catholicos for a ransom, giving the impregnable fortress of Behest (Behesni) to the Egyptian Sultan. ${ }^{282}$ In 1293, the next Armenian Catholicos Ter-Grigor VII (1293-1307) moved the see from Hromklay to Sis. ${ }^{283}$

Mamluk policy towards Cilician Armenia turned out to be more threatening because al-Ashraf aimed to conquer even more than Baybars had. ${ }^{284}$ In the same year, the Mamluk army, stationed at Damascus, received orders to march on Sis but famine and plague, which spread through Egypt and Syria in the same year, halted them. ${ }^{285}$ After the fall of Hŕomklay, the Il-Khan Geikhatu wrote to the Sultan about his intention to sack Aleppo. ${ }^{286}$ However, Geikhatu was threatened by the letters of Sultan al-Ashraf who said he would invade Baghdad, ${ }^{287}$ so no help could be given by the Il-Khan to the Armenians. In contrast to the strong cooperation between Het'um I and the Mongol Il-Khans Abaqa and Arghun, the weak position of King

${ }^{281}$ Nersēs Palients', 1956:181.

${ }^{282}$ Hakobyan, 1956:80; Galstyan, 1962:76. Step'annos Orbelian, the contemporary historian, describes this event differently. He says that the Catholicos TerStep'annos was kept for about a year in prison in Egypt and died there. After his death, King Het'um tried his utmost but he lost the fortress of Behest to the Sultan (Step'annos Orbelian, 1910:444-445). However, both sources are in agreement that the Armenian King lost his fortress to the Sultan.

${ }^{283}$ Galstyan, 1962:129.

284 Stewart, 2001:85.

${ }^{285}$ Der Nersessian, 1973:349.

286 Mikaelean, 1952:427; Amitai, 2005:361.

287 Rashīd al-Dīn, 1946:135; Mikaelean, 1952:427; Boyle, 1968:373. 
Het'um II clearly coincided with the weak reign of Geikhatu Il-Khan, and this was certainly noticed by their enemies.

When al-Ashraf was murdered in December 1293, the Armenians were given breathing space. ${ }^{288}$ However, there were no Franks left in Syria and the Il-Khan Geikhatu was ineffective. In addition to this, in 1290, Genoa had already signed a trading agreement with Egypt to use Alexandria for its spice-trade with India, and King Alfonso III of Aragon (r. 1285-1291) and his brother, King James II of Sicily (r. 1285-1295) had signed a treaty with Cairo. ${ }^{289}$ Het'um II was left alone to act and he decided to strengthen his ties with Cyprus, the only other Christian kingdom surviving in the Levant. During his second reign, in 1295, Het'um II married his sister Zabel to Prince Amaury Lusignan (murdered in 1310), titular Lord of Tyre, and a brother of King Henry II (r. 1285-1324), whose children would later inherit the Cilician throne. ${ }^{290}$

Instability in the Mamluk Sultanate after the death of al-Ashraf gave respite to the Il-Khan as well. ${ }^{291}$ The only success to speak of with regard to the reign of Geikhatu was that he managed to achieve peace with the Golden Horde, receiving with honour the embassy of Toqta Khan (r. 1291-1312) in 1294..$^{292}$ This peace lasted until the reign of Abū Sa'ìd (r. 1316-1335). ${ }^{293}$ Geikhatu and his successor Baidu (1295), whose reign lasted a very short time, left no record of having sent embassies to the West. ${ }^{294}$

Very little is known about the next Il-Khan Baidu, the son of Taragai and grandson of Hülegü, who contested the throne after Geikhatu. ${ }^{295}$ Rashīd al-Dīn mentions Baidu only briefly in connection with Ghazan’s affairs. Qāẹī Baiḍāwī (d. c. 716 H. / 1316) provided a short but important fact about Baidu, saying that after he had ascended the throne, he met Ghazan who came to him. Their talk

${ }^{288}$ Mikaelean, 1952:427; Stewart, 2001:93.

${ }^{289}$ Mikaelean, 1952:425.

290 King Het'um II, 1962:77.

291 The succession crisis of the 1290s: Baydarā al-Qāhir and al-Nāṣir Muhammad (1293), Kitbugha al-'Ābdil (1294), Lachin al-Manșūrī (1296), second reign of al-Nāṣir Muhammad (1298-1308) (Stewart, 2001:93).

${ }_{292}$ Geikhatu's failure in Il-Khanid affairs was caused by his preference for remaining in Anatolia, where he assisted Mongol tax officials to restore revenues in Konya (Melville, 2009:51-101).

${ }^{293}$ Rashīd al-Dīn, 1954:834; Boyle, 1968:374.

294 Jackson, 2005a:170.

295 Rashīd al-Dīn, 1946:19. 
resulted in a clash of armies on both sides. In Siyāhkūh, those who were in the service of Baidu inclined towards Ghazan. Baidu fled but he was caught, brought back and killed in Tabriz. ${ }^{296}$ The discord between Ghazan and Baidu, and the large army possessed by Baidu, are mentioned by al-Jazarī (d. 739 H. / 1339). ${ }^{297}$ The Armenian account in Sebastats'i refers to his short reign saying that it lasted six months, from April until October 1295. ${ }^{298}$ It seems that faith issues also beset Baidu. Step'annos Orbelian believes that Baidu was brought up as a Christian by Maria Despina Palaeologina, Abaqa's wife, along with her children. ${ }^{299}$ It is not clear when Baidu started to adhere to Islam but, according to Bar Hebraeus, the Il-Khan wavered between two faiths, Christian and Muslim; however, his conversion to Islam was symbolic, as he never fasted or prayed. ${ }^{300}$ Baidu was killed by Ghazan, who claimed to be the only legitimate heir to the throne. ${ }^{301}$

The instability of Het'um II, who, according to the chronicler of Cyprus 'had never wanted to be crowned while he was king, but rather wore the habit of the Franciscans and called himself Brother John of Armenia,' regrettably corresponded with the ineffective rules of Geikhatu and Baidu Il-Khans. Not being able to halt the most ambitions plans of the Mamluk Sultan al-Ashraf Khalil, the MongolArmenian partnership declined during their reigns.

Thus, the establishment of the Il-Khanate was a milestone in the Mongol, Muslim and Christian worlds. Within the Mongol Empire, disputes over the Il-Khanid territories led the Il-Khanate, the Golden Horde and the Chaghataid Ulus into a series of conflicts, causing Greater Armenia to suffer under Chinggisid warfare.

The implementation of the Mongols' conquest of the Syrian coast to fulfil their imperial ideology was supported by the Armenians, whose interest was based not only on the idea of the liberation of the Holy Land, but also on their need to safeguard their lands. Mamluk interest in controlling the Syrian coast was far more than for purely geographical or religious reasons: There was great economic concern

${ }^{296}$ Melville, 2007:54-55, 62.

297 Melville, 1990a:162-63.

298 Sebastats'i in Hakobyan, 1956:150. Baiḍāwī says that Baidu’s reign lasted seven months (Melville, 2007:62).

299 Step'annos Orbelian, 1910:470.

300 Bar Hebraeus, 2003:505.

${ }^{301}$ Manandian, 1952:305; Spuler, 1989:887-888. 
to control the resources and trade routes of the region. With the end of the Crusader epoch, the threat from Europe became meaningless, enabling Mamluks to reinforce their Egyptian power-base against the Mongols. Another party who tried to secure a place in MongolMamluk affairs was the Byzantine Emperor Michael VIII Palaeologus, who acted with political insight, courting the Mongols of the Golden Horde and the Il-Khanate and facilitating the successful operation of a trading zone by the Mamluks and the Golden Horde.

From 1265 to 1295, Mongol-Armenian collaboration against the Mamluks was exemplified by major pairings. Among these, the joint ventures of Abaqa and Het'um I were the most organised and victorious in achieving their goals. The partnership of Abaqa and Lewon III was the most productive in appealing to the Latin West. The duo of Arghun and Lewon III as allies was strong enough, although this collaboration had the most shameful result as it allowed the Armenian Kingdom to sign a ten-year tributary agreement with the Mamluk Sultanate. It is also worth noting that strong Mongol Il-Khans coincided with powerful colleagues in the Armenian Kingdom, for instance Abaqa and Het' um I, and Arghun and Lewon III. The reigns of weak Il-Khans coincided with those of weak Armenian kings.

Serious Mamluk political and economic challenges ensured the Cilician Armenians to stay close to their allies, the Il-Khans. However, the nature of the Il-Khanid relations with the Cilicia altered. This was followed by the series of appeals, both by the Armenians and the Il-Khans, to the Papacy. Their correspondence with the Latin powers, including the Kings of France and England, remains an excellent illustration of medieval diplomacy. These events established an exclusive multi-functional relationship, forcing the Mongols, Armenians, Mamluks and the Christian West into various collaborative efforts.

The Cilician Armenians were enthusiastic in appealing directly to the Il-Khans to liberate the Syrian coast from the Muslims. The Cilician Armenian interest in this venture was obvious. The question of the liberation of the Holy Land by the Mongols is still intriguing. The Latin hesitation in assisting the Mongols was also understandable. However, Mongol raids into Syria allowed the Armenian kingdom of Cilicia to reclaim lands lost to the Mamluks, although these repossessions had a temporary character. Through this collaboration with the Mongols, the Cilician Armenians became a direct target of the Mamluk Sultans. 
Conditions in Greater Armenia in particular, and the Caucasus in general, deteriorated with the intensification of hostilities between the Il-Khanate and the other Chinggisid Uluses. Provisioning and accommodating one or another party of Mongol Khans became a laborious game to play for the people of the region. However, Greater Armenia's interests lay more on the Il-Khanid side than on that of the other Chinggisids. 